\title{
Experimental intracerebral haemorrhage: the effect of nimodipine pretreatment
}

\author{
E J SINAR, * A D MENDELOW,* D I GRAHAM, $\dagger$ G M TEASDALE $\dagger$ \\ From the Department of Neurosurgery,* Newcastle General Hospital, Newcastle Upon Tyne, and the \\ Departments of Neurosurgery and Neuropathology, $\dagger$ University of Glasgow, Scotland, UK
}

SUMMARY The effect of pretreatment with the calcium antagonist nimodipine on the pathophysiological events which follow an intracerebral haemorrhage in rats was compared with a similar control group. Cerebral blood flow was higher and the amount of pathologically determined ischaemic damage measured by light microscopy was less in the nimodipine pretreated group. Bloodbrain barrier permeability was increased in the nimodipine group, but there was no evidence of cerebral oedema. Nimodipine appeared to have no effect on the intracranial pressure.

The management of intracerebral haemorrhage occurring either spontaneously or secondary to rupture of an aneurysm remains controversial and the mortality is often high. ${ }^{1-5}$ Undoubtedly much tissue damage and distortion occur at the time of formation of the haematoma,${ }^{67}$ but secondary ischaemic events may also be important, ${ }^{89}$ and may be susceptible to treatment.

The calcium antagonist nimodipine has been shown to be capable of increasing cerebral blood flow $(\mathrm{CBF})^{1011}$ without affecting oxygen uptake and glucose utilisation in different animal models of cerebral ischaemia. ${ }^{12}$ Also it has been reported to reduce the amount of ischaemic damage following various periods of reduced CBF in animal models, particularly if treatment begins before the ischaemic event. ${ }^{13-15}$ In addition it has been used in clinical trials involving patients with the purpose of preventing or reversing delayed cerebral ischaemia following subarachnoid haemorrhage. ${ }^{15-19}$ However, the effects of nimodipine pretreatment on the pathophysiological events produced by an intracerebral haemorrhage have not yet been determined.

The aim of this study was to investigate the effect of nimodipine pre-treatment on regional cerebral blood flow (rCBF) following an intracerebral haemorrhage, and to correlate these changes in $\mathrm{rCBF}$ with any

Address for reprint requests: Mr E J Sinar, Department of Neurosurgery, Regional Neurological Centre, Newcastle General Hospital, Westgate Road, Newcastle upon Tyne NE4 6BE, UK.

Received 19 May 1987 and in revised form 11 November 1987. Accepted 17 November 1987. changes in the volume of ischaemic damage, intracranial pressure (ICP), brain specific gravity (SG), and blood-brain barrier (BBB) permeability.

\section{Materials and methods}

\section{General preparation}

Experiments were performed on anaesthetised, physiologically monitored, adult male Sprague-Dawley rats weighing 360-439 g. The general preparation was identical to that previously described elsewhere. ${ }^{20}$ After a 30 -minute stabilisation period, in half the animals an intravenous infusion of nimodipine was commenced at the rate of $1 \mu \mathrm{g} \mathrm{kg}^{-1} \min ^{-1}$. In the remaining animals vehicle (polyethylene glycol-ethanol-water mixture) was infused at the same rate, this group serving as controls. Thirty minutes following the start of the infusion fresh, non-heparinised, autologous arterial blood was taken from a femoral artery and used to prime a blunted 25-gauge butterfly needle. This was then inserted stereotactically to a depth of $5.5 \mathrm{~mm}$ into the right caudate nucleus. The burr hole was sealed with dental cement and $100 \mu \mathrm{l}$ of the arterial blood introduced into the right caudate nucleus in all animals at arterial pressure $(100 \mathrm{mmHg})$ from a constant pressure reservoir. Following production of the intracerebral haemorrhage the infusion of nimodipine or vehicle was continued at the previously stated rate for 4 hours. During this time the $\mathrm{PaO}_{2}$ was maintained above $100 \mathrm{mmHg}$, the $\mathrm{PaCO}_{2}$ between 35 and $40 \mathrm{mmHg}$, the mean arterial blood pressure (MABP) above $80 \mathrm{mmHg}$, and the plasma glucose concentration and haematocrit were measured every 30 minutes. The temperature was monitored by means of a rectal thermistor probe and maintained at $37^{\circ} \mathrm{C}$ by means of an electric heating lamp. Any animal not fulfilling these physiological criteria was excluded from the series. The experiments were performed on a double-blind basis, the code remaining unbroken until all the experiments had been completed and the results analysed. 


\section{Experimental groups}

The animals were divided into four groups each containing an equal number of nimodipine and vehicle treated animals.

Group $1(n=12)$ : Neuropathology

Four hours following production of the intracerebral haemorrhage the animals were perfusion-fixed for neurological purposes using the method of Brierley et al. ${ }^{21}$ The brains were removed and using the histological criteria of Brown and Brierley ${ }^{27}$ the area of ischaemic damage at predetermined coronal levels was calculated, ${ }^{20}$ the anterior coordinates of which are given in table 1 . The co-ordinates for the coronal levels were taken from the stereotaxic areas of Konig and Klippel. ${ }^{23}$ An approximation to total volume of ischaemic damage was then achieved by integration of the areas with the distance between each level using a microcomputer. Great care was taken to exclude the volume of the needle and haematoma from the total. The amount of ischaemic damage was then expressed as a percentage of the volume of the cerebral hemisphere, cerebral cortex and caudate nucleus, as well as in the absolute volume $\left(\mathrm{mm}^{3}\right)$.

Group $2(n=12)$ : Measurement of intracranial pressure, brain specific gravity, and repeated measurement of cortical blood flow using hydrogen clearance

In this group of animals intracranial pressure was measured continuously during the course of the experiments via a ventricular catheter. ${ }^{20}$ In addition, to allow repeated measurement of cerebral blood flow using hydrogen clearance, two further burr holes were made one on either side of the saggital suture $2.8 \mathrm{~mm}$ lateral and $4 \mathrm{~mm}$ anterior to the bregma. Platinum electrodes (external diameter $200 \mathrm{~mm}$ ) were inserted stereotactically under direct microscopic vision to a depth of $1 \mathrm{~mm}$ into the frontal cortex (1 electrode per burr hole). A silver/silver chloride reference electrode was inserted subcutaneously in the dorsal thoracic region and a polarising voltage of $700 \mathrm{mV}$ applied. Hydrogen was introduced into the system at a concentration of $12 \%$ of inspired gases and discontinued once saturation had occurred, usually after 5 minutes. CBF was calculated by analysis of the initial slope of the clearance curve. ${ }^{24}$ Flows were measured initially at rest, 30 minutes after the start of infusion of nimodipine or vehicle, 5 minutes after production of the haematoma and thereafter every 30 minutes until the end of the experiment. Four hours following the production of the intracerebral haemorrhage, asystole was

Table 1 Anatomical landmarks

\begin{tabular}{lcl}
\hline & Level & $\begin{array}{l}\text { Anterior } \\
\text { Co-ordinates }(\mathrm{mm})\end{array}$ \\
\hline Caudate nucleus & 1 & $9 \cdot 65$ \\
Genu corpus callosum & 2 & $8 \cdot 92$ \\
Nucleus accombens & 3 & $8 \cdot 38$ \\
Septal nuclei & 4 & $7 \cdot 47$ \\
Anterior commisure & 5 & $7 \cdot 02$ \\
Fornix & 6 & $6 \cdot 79$ \\
Globus pallidus & 7 & $6 \cdot 36$ \\
Commissure of the fornix & 8 & $5 \cdot 91$ \\
Habenula & 9 & $5 \cdot 34$ \\
Fimbria hippocampi & 10 & $4 \cdot 62$ \\
Lateral habenula & 11 & $4 \cdot 11$ \\
\hline
\end{tabular}

Anatomical landmarks of coronal sections of the rat brain from König and Klippel, 1974. produced with an intravenous bolus of potassium chloride and Euthatal, and brain specific gravity measured using a microgravimetric method. ${ }^{25}$

\section{Group $3(n=12)$ : Measurement of regional cerebral blood} flow at 4 hours

Regional cerebral blood flow (rCBF) was measured at the end of 4 hours using the ${ }^{14} \mathrm{C}$ iodo-anti pyrine technique ${ }^{26}$ as described previously. ${ }^{20}$ For analysis of the CBF data both the standard method of microdensitometry and an area based method were used. ${ }^{20}$ When using the area based method great care was taken to exclude the area of the needle and haematoma. The percentage area of cerebral cortex, cerebral hemisphere, and caudate nucleus with the rCBF below a particular range was then calculated for flow ranges of $10 \mathrm{ml} .100 \mathrm{gm}^{-1} \mathrm{~min}^{-1}$ up to and including 200 $\mathrm{ml} .100 \mathrm{gm}^{-1} \mathrm{~min}^{-1}$ in increments of $10 \mathrm{ml} .100 \mathrm{gm}^{-1}$

\section{Group 4 (No 12): Measurement of blood-brain barrier permeability at 4 hours using the aminoisobutyric acid autoradiographic technique}

The general preparation was the same as already described. At the end of 4 hours the blood-brain barrier (BBB) permeability was measuring using the ${ }^{14} \mathrm{C}-\alpha$ aminoisobutyric acid (AIB) technique described by Blasberg et al. ${ }^{27}$ An infusion of $75 \mu \mathrm{Ci}$ of ${ }^{14} \mathrm{C} \mathrm{AIB}$, made up to a total volume of $1.5 \mathrm{ml}$ with normal saline, was given over 25 seconds. Simultaneously, commencing at the start of the infusion serial samples of arterial blood were taken (100-150 $\mu \mathrm{l})$ and rapidly centrifuged. Frequent blood samples were drawn early in the experimental time course $(0,0 \cdot 25,0 \cdot 5,0 \cdot 75,1 \cdot 0,2 \cdot 0,3 \cdot 0,5 \cdot 0$, 7.5 and $10 \mathrm{~min})$ as the plasma levels of isotope were changing rapidly during this period. Later plasma samples changed more slowly and the sampling interval was lengthened correspondingly $(12.5,15.0,20.0 \mathrm{~min})$. Subsequently $27.5 \mu$ l of plasma was pipetted into counting vials for determinätion of radioactivity by liquid scintillation counting. Immediately after the last sample had been taken, asystole was produced with an intravenous bolus of potassium chloride/euthatal. Circulatory failure was taken from the time when the MABP had been reduced to 50 of baseline and the time noted. The brain was rapidly removed and frozen in isopentane at $-45^{\circ} \mathrm{C}$, following which $20 \mu \mathrm{m}$ thick sections were cut in a cryostat at $-22^{\circ} \mathrm{C}$. Three adjacent sections every $400 \mu \mathrm{m}$ were saved, increasing to three sections every $200 \mu \mathrm{m}$ in the region of the lesion. The sections were mounted on glass cover slips and immediately dried on a hotplate. Autoradiographs were prepared by exposing the sections together with a set of plastic standards of known ${ }^{14} \mathrm{C}$ concentration (44-1175 $\mu \mathrm{Ci}^{-1}$ ) to single-coated $\mathrm{x}$-ray film (Kodak SB5) for 6 weeks.

Changes in BBB permeability were then assessed from the resulting ${ }^{14} \mathrm{C}$ - $\alpha \mathrm{AIB}$ autoradiographs (fig 6 ). Sample readings were taken at 17 discrete neuroanatomically determined loci, with reference to the ${ }^{14} \mathrm{C}$ standards, using a computer-based densitometer (Quantimet 720, Cambridge Instruments). The capillary transfer constant $\left(\mathrm{K}_{1}\right)$ for ${ }^{14} \mathrm{C}-\alpha$-AIB was then calculated at each locus.

\section{Statistics}

All values are expressed as means and the standard error of the mean. The means were compared using both Scheffe and 
Table 2 Physiological variables in the two groups $(N=48$ : mean values, $S E M)$

\begin{tabular}{|c|c|c|c|c|c|c|}
\hline & \multicolumn{2}{|l|}{ Arterial pH } & \multicolumn{2}{|c|}{ Arterial $\mathrm{PaO}_{2} \mathrm{mmHg}$} & \multicolumn{2}{|c|}{ Arterial $\mathrm{PaCO}_{2} \mathrm{mmHg}$} \\
\hline & Nimodipine & Vehicle & Nimodipine & Vehicle & Nimodipine & Vehicle \\
\hline $\begin{array}{l}\text { Resting } \\
\text { Infusion for } 30 \text { minutes } \\
5 \mathrm{~min} \text { post haemorrhage } \\
30 \mathrm{~min} \\
60 \mathrm{~min} \\
90 \mathrm{~min} \\
120 \mathrm{~min} \\
150 \mathrm{~min} \\
180 \mathrm{~min} \\
210 \mathrm{~min} \\
240 \mathrm{~min} \\
\text { Resting } \\
\text { Infusion for } 30 \text { minutes } \\
5 \mathrm{~min} \text { post haemorrhage } \\
30 \mathrm{~min} \\
60 \mathrm{~min} \\
90 \mathrm{~min} \\
120 \mathrm{~min} \\
150 \mathrm{~min} \\
180 \mathrm{~min} \\
210 \mathrm{~min} \\
240 \mathrm{mins}\end{array}$ & 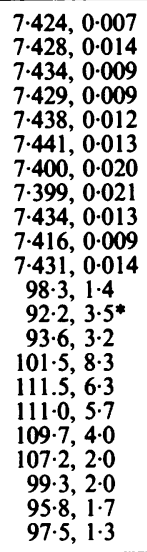 & 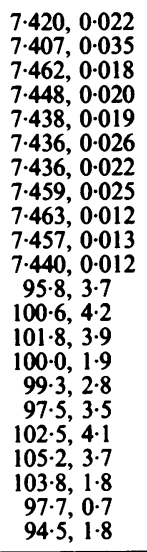 & $\begin{array}{l}145 \cdot 9,7 \cdot 7 \\
148 \cdot 5,7 \cdot 0 \\
160 \cdot 0,5 \cdot 6 \\
162 \cdot 6,6 \cdot 1 \\
162 \cdot 8,5 \cdot 2 \\
160 \cdot 7,4 \cdot 2 \\
163 \cdot 2,4 \cdot 9 \\
170 \cdot 2,5 \cdot 9 \\
169 \cdot 5,7 \cdot 4 \\
144 \cdot 2,8 \cdot 2 \\
161 \cdot 7,8 \cdot 6 \\
9 \cdot 8,0 \cdot 4 \\
11 \cdot 6,0 \cdot 3 \dagger \\
11 \cdot 2,0 \cdot 4 \dagger \\
11 \cdot 4,0 \cdot 2 \dagger \\
11 \cdot 2,0 \cdot 6 \\
11 \cdot 2,0 \cdot 5 \\
11 \cdot 3,0 \cdot 6 \\
11 \cdot 3,0 \cdot 5 \\
10 \cdot 9,0 \cdot 5 \\
10 \cdot 8,0 \cdot 4 \dagger \\
10 \cdot 9,0 \cdot 4 \dagger\end{array}$ & $\begin{array}{l}140 \cdot 2,12 \cdot 2 \\
137 \cdot 2,9 \cdot 2 \\
151 \cdot 6,7 \cdot 3 \\
144 \cdot 7,6 \cdot 6 \\
141 \cdot 0,10 \cdot 5 \\
145 \cdot 9,6 \cdot 8 \\
147 \cdot 5,9 \cdot 2 \\
146 \cdot 7,8 \cdot 2 \\
148 \cdot 0,6 \cdot 2 \\
140 \cdot 6,8 \cdot 4 \\
145 \cdot 4,4 \cdot 4 \\
9 \cdot 8,9 \cdot 5 \\
9 \cdot 1,0 \cdot 5 \\
9 \cdot 4,0 \cdot 4 \\
9 \cdot 1,0 \cdot 4 \\
9 \cdot 3,0 \cdot 3 \\
9 \cdot 7,0 \cdot 5 \\
8 \cdot 9,0 \cdot 3 \\
9 \cdot 2,0 \cdot 5 \\
9 \cdot 6,0 \cdot 4 \\
9 \cdot 2,0 \cdot 2 \\
9 \cdot 0,0 \cdot 2\end{array}$ & $\begin{array}{l}38 \cdot 9,0 \cdot 4 \\
37 \cdot 7,0 \cdot 7 \\
37 \cdot 6,0 \cdot 8 \\
38 \cdot 5,0 \cdot 5 \\
37 \cdot 6,0 \cdot 6 \\
37 \cdot 2,0 \cdot 7 \\
37 \cdot 3,0 \cdot 8 \\
36 \cdot 6,0 \cdot 4 \\
37 \cdot 7,0 \cdot 5 \\
36 \cdot 6,0 \cdot 5 \\
37 \cdot 0,0 \cdot 3 \\
46,1 \cdot 0 \\
47,1 \cdot 1 \\
45,0 \cdot 4 \\
48,0 \cdot 7 \\
47,1 \cdot 0 \\
44,1 \cdot 2 \\
45,1 \cdot 1 \\
46,1 \cdot 4 \\
47,0 \cdot 9 \\
50,0 \cdot 7 \\
49,0 \cdot 9\end{array}$ & $\begin{array}{l}37 \cdot 1,0 \cdot 9 \\
36 \cdot 6,1 \cdot 1 \\
37 \cdot 6,0 \cdot 5 \\
37 \cdot 7,0 \cdot 6 \\
38 \cdot 0,0 \cdot 8 \\
37 \cdot 9,0 \cdot 7 \\
36 \cdot 8,0 \cdot 8 \\
36 \cdot 6,0 \cdot 6 \\
36 \cdot 9,0 \cdot 6 \\
36 \cdot 8,0 \cdot 3 \\
37 \cdot 6,0 \cdot 3 \\
44,1 \cdot 1 \\
45,1 \cdot 0 \\
45,1 \cdot 3 \\
46,0 \cdot 3 \\
45,1 \cdot 3 \\
44,1 \cdot 7 \\
44,1 \cdot 7 \\
46,1 \cdot 1 \\
46,1 \cdot 1 \\
48,0 \cdot 8 \\
50,1 \cdot 1\end{array}$ \\
\hline
\end{tabular}

${ }^{*} \mathrm{p}<0.05$ (unpaired $t$ test)

$t \mathrm{p}<0.01$ (unpaired $t$ test)

tsignificant difference between the two groups

Student's unpaired $t$ tests. Student's tests were used where a priori hypotheses were recorded before the experiments were conducted; Scheffe tests, being more rigorous and less likely to show up differences, were used for all other comparisons. Significance was taken as $\mathrm{p}<0.05$.

\section{Results}

\section{Physiological variables}

Table 2 shows the physiological variables in the two groups of animals. There was not a significant difference in the $\mathrm{PaO}_{2}, \mathrm{PaCO}_{2}, \mathrm{pH}$ or the haematocrit between the two groups during the course of the experiments. Thirty minutes following the start of the infusion the MABP in the nimodipine group had fallen to $92 \cdot 2,3.5 \mathrm{mmHg}$ compared with $100 \cdot 6,4 \cdot 2$ $\mathrm{mmHg}$ in the vehicle group. This difference was statistically significant ( $\mathrm{p}<0.05$, unpaired $t$ test) and remained so until $\mathbf{3 0}$ minutes after the production of the ICH. Thirty minutes following commencement of the infusion the arterial plasma glucose concentration had risen significantly ( $\mathrm{p}<0.01$, unpaired $t$ test) to $11.6,0.3 \mathrm{mmol} / 1$ in the nimodipine group compared with $9 \cdot 1,0.5 \mathrm{mmol} / 1$ in the vehicle group. The difference between the two groups remained significant until the end of the experiment.

\section{Neuropathological findings}

Perfusion fixation was excellent in all animals, as shown by the absence of intravascular blood, good neuronal morphology and the lack of cytological artefacts such as "dark cell" and "hydropic cell" changes. All the brains examined had an intracerebral haematoma present in the ipsilateral caudate nucleus, although the configuration varied from animal to animal. Three animals in each group had a small haematoma overlying the ipsilateral cerebral cortex adjacent to the needle tract. No animal in either group had a haematoma in the contralateral cerebral hemisphere or overlying the contralateral cerebral cortex.

Each of the brains examined had some degree of ischaemic damage adjacent to the needle track in the ipsilateral cerebral cortex, the degree of damage being similar in both groups. However the amount of cortical damage was greatly increased in the six animals that had cortical haematomas present. Around each intracaudate haematoma was a zone of ischaemic damage varying in shape according to the configuration of the haematoma. No animal in either group had evidence of ischaemic damage in the contralateral cerebral hemisphere. Figure 1 shows the typical appearance of an animal pre-treated with nimodipine and one receiving vehicle.

Quantification of the volume of ischaemic damage from the brain maps (fig 2) showed that in the vehicle group $15 \pm 4 \%$ of the ipsilateral caudate nucleus showed signs of ischaemic damage compared with only $7 \pm 2 \%$ in the nimodipine group, a difference of $113 \%$ (table 3). Despite this definite trend, there was some variability in the volume of ischaemic damage from animal to animal. This resulted in the difference in mean values not being statistically significant ( $p>0.05<0.1$, unpaired $t$ test). However, quantification of the area of ischaemic damage at each 


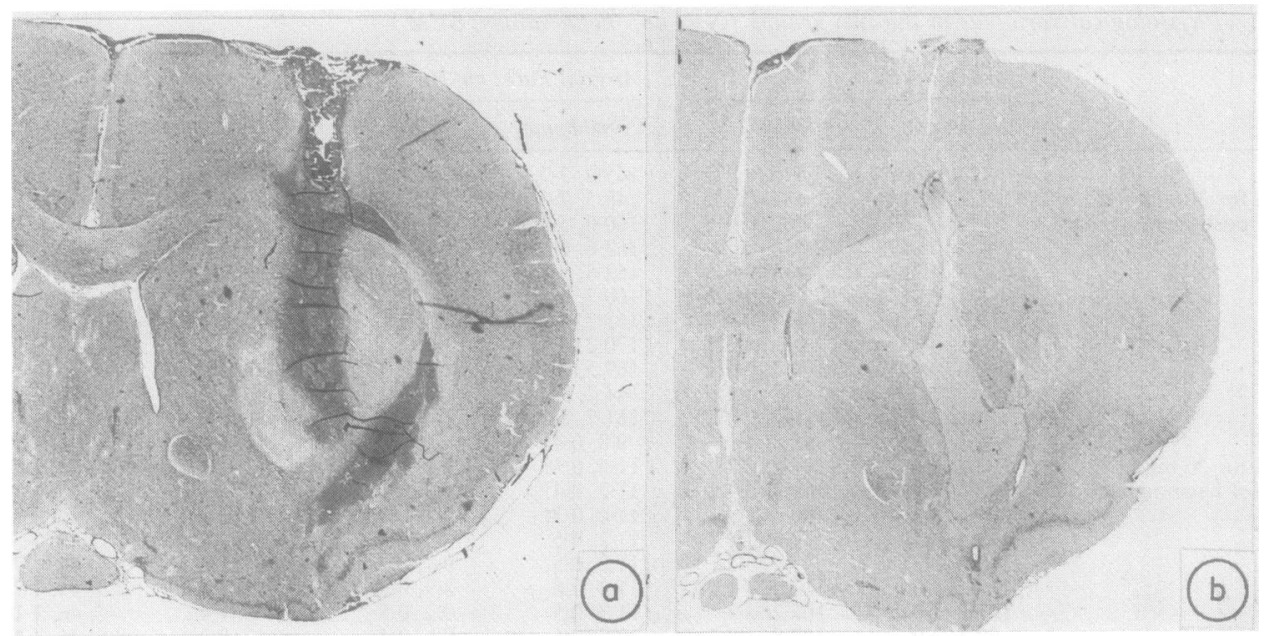

Fig 1 Histological sections of the ipsilateral cerebral hemisphere at the level of the caudate nucleus. The sections show the typical appearance of an animal pre-treated with vehicle (a) and one with nimodipine (b). Present in each caudate nucleus is a haematoma, although its visible size in these illustrations is reduced by the decolourising effect of FAM. Note the area of ischaemia around the haematoma $(H \& E \times 10)$.

area of the coronal levels (fig 3 ) revealed that anteriorly at level 1 (caudate nucleus), at which damage was maximum, there was a significant reduction in the amount of ischaemic damage in the nimodipine group compared to the vehicle group $(\mathrm{p}<0.05$, unpaired $t$ test). Similar differences were seen in the volume of ischaemic damage in the cerebral cortex and cerebral hemisphere between the two groups (table 3), but these differences were not significant.

\section{ICP Responses and brain specific gravity measurements}

The changes in ICP in the two groups of animals during the course of the experiments are summarised in table 4. Before the start of infusion of nimodipine or vehicle the resting ICP was the same in both groups (4,0 and 4,1 $\mathrm{mmHg}$ respectively). After 30 minutes' infusion of nimodipine or vehicle, the ICP did not alter in either group. Immediately following production of the intracerebral haemorrhage there was a significant rise in ICP in both groups of animals to reach $41,6 \mathrm{mmHg}$ in the nimodipine group and 44,6 mmHg in the vehicle group ( $\mathrm{p}<0.01$, unpaired $t$ test). ICP in both groups fell over the next 30 minutes before rising again but never attaining the level recorded immediately after production of the haemorrhage. At the end of the 4-hour period ICP in both groups remained significantly above resting levels ( $<<0.05$, unpaired $t$ test). At no time was there a significant difference in ICP between the two groups.

Table 5 summarises the brain specific gravity (SG) measurements in the two groups of animals. The SG measurements did not differ significantly between the two groups of animals at 4 hours following production of the intracerebral haemorrhage. None of the measurements were of an order which suggested that oedema formation had taken place.

Cerebral blood flow measurements from the ${ }^{14} \mathrm{C} I A P$ autoradiographs

Figure 4 shows the autoradiographic appearance of an animal receiving nimodipine and of one receiving vehicle, 4 hours following the production of an intracerebral haemorrhage.

(1) Discrete anatomical loci Table 6 shows the values of rCBF measured in 21 pre-determined neuroanatomical loci in both groups of animals. All measurements were made 4 hours following production of the intracerebral haemorrhage. Because of its size and because it was the site of the lesion, the caudate nucleus was divided into three regions: ante-

Table 3 Volume per cent of ischaemic damage $(N=12:$ mean values, $S E M)$

\begin{tabular}{llr}
\hline & \multicolumn{2}{l}{ Ipsilateral } \\
\cline { 2 - 3 } Volume \% & Nimodipine & \multicolumn{1}{l}{ Vehicle } \\
\hline Cerebral hemisphere & $2 \cdot 6,0 \cdot 9$ & $4 \cdot 1,1 \cdot 3$ \\
Cerebral cortex & $4 \cdot 3,1 \cdot 7$ & $6 \cdot 0,3 \cdot 0$ \\
Caudate nucleus & $7 \cdot 2,1 \cdot 7$ & $15 \cdot 4,3 \cdot 8$ \\
\hline
\end{tabular}

Only ipsilateral structures are considered, contralateral structures being free from damage. 

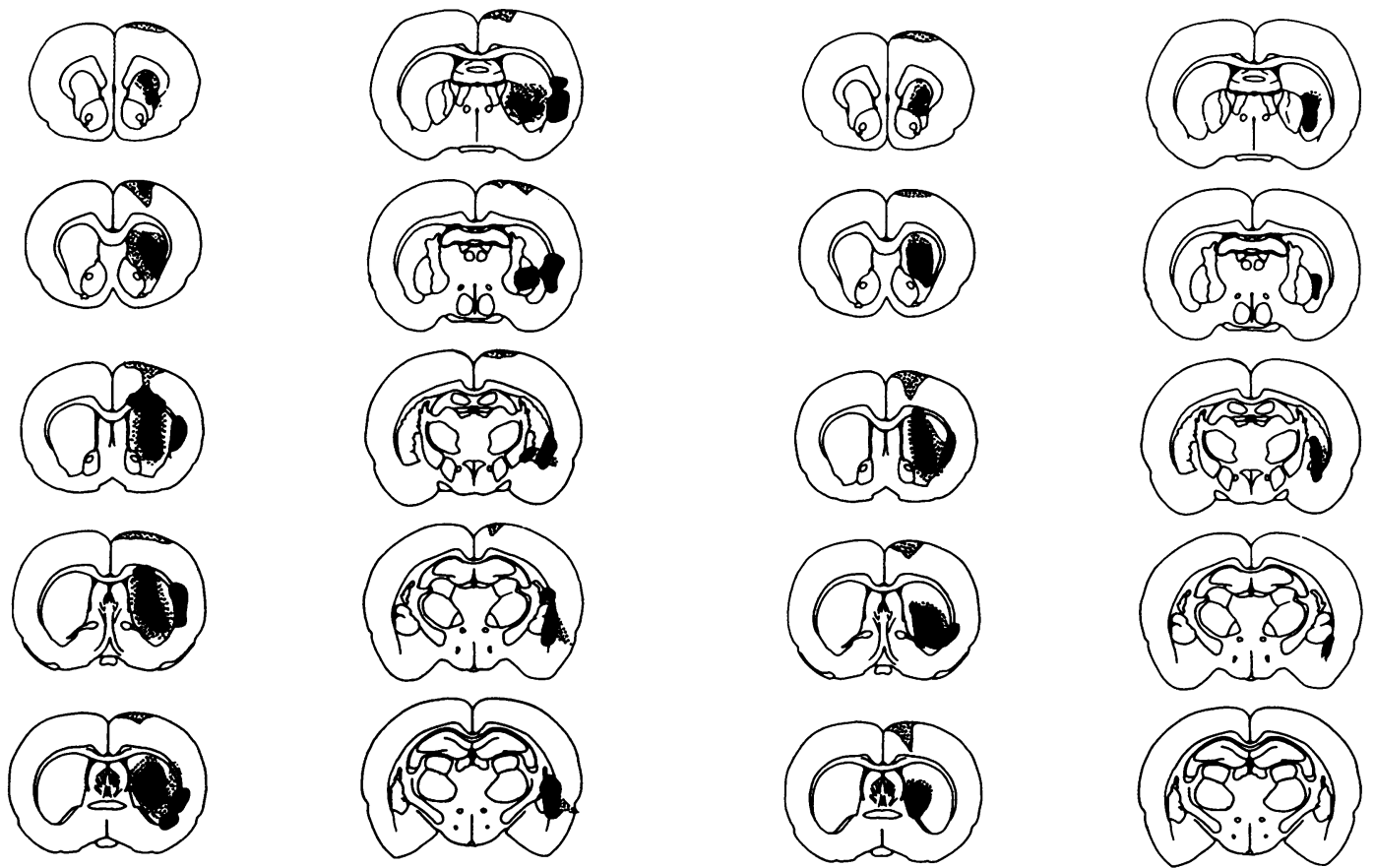

(a)

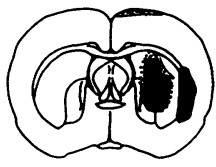

(b)

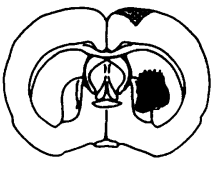

Fig 2 Diagram to show the extent of intracerebral haemorrhage and resulting ischaemic damage in a vehicle-treated animal (a) and one receiving nimodipine (b). In both groups the haematoma is confined mainly to the caudate nucleus, surrounded in turn by a zone of ischaemic damage. The dark areas represent the extent of the haematoma, the stippled area the extent of ischaemic damage.

rior, middle and posterior, areas of high and low flow being measured in each region. The $\mathrm{rCBF}$ in the ipsilateral caudate nucleus of both groups was reduced compared with that in the corresponding contralateral caudate nucleus. The reduction was significant at three levels (anterior low, middle low and posterior low) in the vehicle group, but at only two levels (anterior low and middle low) in the nimodipine group. In addition there was a trend for the reduction in $\mathrm{rCBF}$ in the nimodipine group to be less than in the vehicle group, in areas of both high and low flows. Anteriorly in areas of low flow the ipsilateral caudate nucleus of the nimodipine group had an rCBF of $70,17.6 \mathrm{ml} 100 \mathrm{~g}^{-1} \mathrm{~min}^{-1}$ compared with only $41,11.2 \mathrm{ml} 100 \mathrm{~g}^{-1} \mathrm{~min}^{-1}$ in the vehicle
Table 4 Intracranial pressure measurements in the two groups of animals during the course of the experiments.

\begin{tabular}{|c|c|c|}
\hline Intracranial pressure $(\Lambda$ & $\begin{array}{l}n \text { values, } S E M \\
\text { Nimodipine }\end{array}$ & $\underset{\text { Vehicle }}{\operatorname{mmHg}))}$ \\
\hline $\begin{array}{l}\text { Resting } \\
30 \text { minutes of infusion } \\
\text { Production of haematoma } \\
30 \mathrm{~min} \text { post haematoma } \\
60 \mathrm{~min} \\
90 \mathrm{~min} \\
120 \mathrm{~min} \\
150 \mathrm{~min} \\
180 \mathrm{~min} \\
210 \mathrm{~min} \\
240 \mathrm{~min}\end{array}$ & $\begin{array}{l}4,0 \cdot 4 \\
4,1 \cdot 0 \\
41,6 \cdot 0 \dagger \\
16,4 \cdot 0 \\
17,3 \cdot 0 \\
19,2 \cdot 0 \\
22,3 \cdot 0 \\
23,2 \cdot 0 \\
20,4 \cdot 0 \\
22,2 \cdot 0 \\
21,7 \cdot 0^{*}\end{array}$ & $\begin{array}{l}4,1 \cdot 0 \\
4,1 \cdot 0 \\
44,6 \cdot 0 \dagger \\
19,4 \cdot 0 \\
20,3 \cdot 0 \\
21,3 \cdot 6 \\
23,2 \cdot 0 \\
24,1 \cdot 2 \\
25,2 \cdot 4 \\
26,4 \cdot 0 \\
25,6 \cdot 0^{*}\end{array}$ \\
\hline
\end{tabular}

${ }^{*} \mathrm{p}<0.05$ (unpaired $t$ test)

tp $<0.01$ (unpaired $t$ test)

tsignificant differences compared to the corresponding resting ICP 


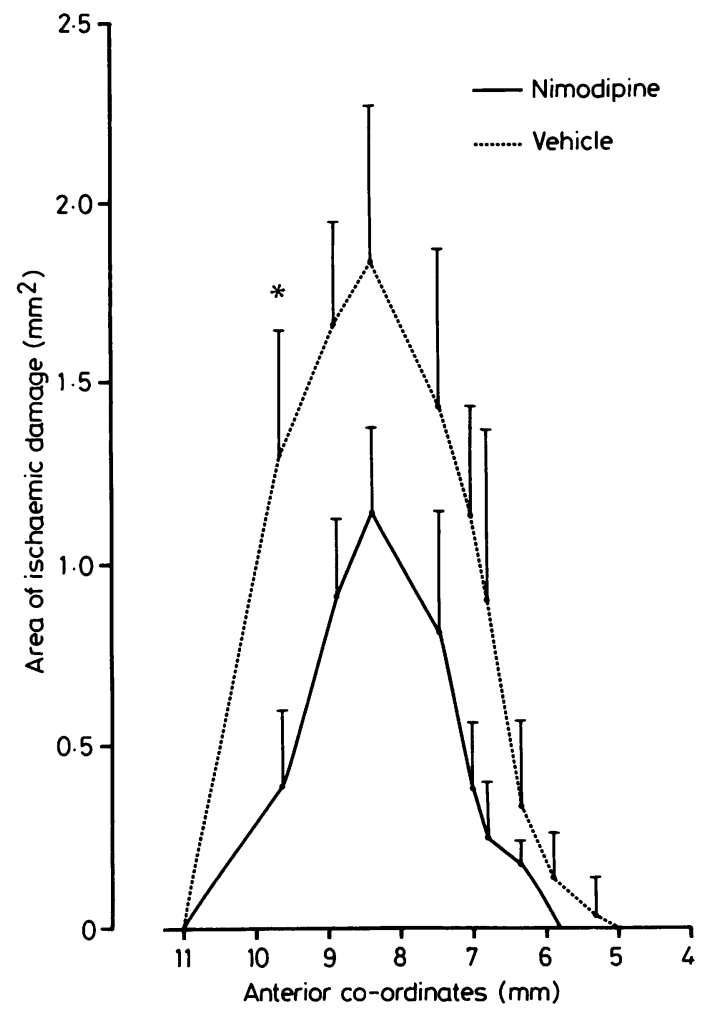

Fig 3 Area of ischaemic damage at each of the coronal levels. ${ }^{*}$ significant difference between the groups $(p<0.05$, unpaired $t$ test). (All values, SEM).

group, a difference of $70 \cdot 7 \%$. Similar differences existed more posteriorly in the caudate nucleus $(60$, $15.6 \mathrm{ml} 100 \mathrm{~g}^{-1} \mathrm{~min}^{-1}$ in the nimodipine group compared with $42,12.8 \mathrm{ml} 100 \mathrm{~g}^{-1} \mathrm{~min}^{-1}$ in the vehicle group, a $42.8 \%$ difference). Similarly rCBF in the ipsilateral frontal cortex of the nimodipine group was $150,31.5 \mathrm{ml} 100 \mathrm{~g}^{-1} \mathrm{~min}^{-1}$ compared to $117,29.0 \mathrm{ml}$ $100 \mathrm{~g}^{-1} \mathrm{~min}^{-1}$ in the vehicle group (a difference of $28 \%$ ). However, owing to the high degree of variability in the two groups of animals, there were not any significant differences between the two groups in the rCBF values in the caudate nucleus ( $\mathrm{p}>0.05<0.1$, unpaired $t$ test). Differences in the rCBF values between the two groups were also seen in the cingulate and frontal cortices but again did not reach significance (Scheffe test).

(2) Range of flows The range of flow values was analysed by measuring and calculating the percentages of each caudate nucleus, cerebral hemisphere and cerebral cortex having an $\mathrm{rCBF}$ within a particular range, as previously described. These results are shown graphically in fig 5 . As with rCBF values measured at the pre-determined neuroanatomical loci, the overall picture was for structures ipsilateral to the lesion in the nimodipine group to have higher rCBF values than the corresponding side in the vehicle group. Thus $7 \cdot 4,3.2 \%$ of the ipsilateral caudate nucleus in the vehicle group had a flow less than $20 \mathrm{ml}$ $100 \mathrm{~m}^{-1} \min ^{-1}$ compared with $4.9,1.8 \%$ in the nimodipine group. In the vehicle group $7 \cdot 5,2.5 \%$ of the ipsilateral cerebral hemisphere had a flow less than $20 \mathrm{ml} 100 \mathrm{~g}^{-1} \mathrm{~min}^{-1}$ compared with $3 \cdot 5,1 \cdot 4 \%$ of the same side in the nimodipine group. In the cerebral cortex the values were similar in both groups: $3 \cdot 8$, $1.9 \%$ (vehicle) and $3 \cdot 5,1 \cdot 1 \%$ (nimodipine).

Cortical blood flow measurements using the $\mathrm{H}^{+}$ clearance technique

Table 7 summarises changes in $\mathrm{rCBF}$ in the adjacent frontal cortex in both groups of animals during the course of the experiments using the $\mathrm{H}^{+}$clearance technique. Measurement of $\mathrm{rCBF}$ at rest showed that there was not a significant difference between the two groups of animals (either ipsi- or contralaterally). Thirty minutes following the start of the infusion rCBF had risen significantly in the ipsilateral frontal cortex of the nimodipine group $\left(69,3.6 \mathrm{ml}^{100 \mathrm{~g}^{-1}}\right.$ $\left.\min ^{-1}\right)$ compared with the same side in the vehicle group $\left(51,5.7 \mathrm{ml} 100 \mathrm{~g}^{-1} \mathrm{~min}^{-1}\right)(\mathrm{p}<0.05$, unpaired $t$ test).

Following production of the intracerebral haemorrhage there was a reduction in cortical rCBF bilaterally in both groups, although the reduction was

Table 5 Regional specific gravity measurements in the two groups of animals four hours following production of the intracerebral haematoma

\begin{tabular}{|c|c|c|c|c|}
\hline & \multicolumn{4}{|c|}{ Regional specific gravity measurements $(N=12$ : mean values, $S E M)$} \\
\hline & Ipsilateral & Contralateral & Ipsilateral & Contralateral \\
\hline Frontal cortex & $\begin{array}{l}1.0610 \\
0.0060\end{array}$ & $\begin{array}{l}1.0531 \\
0.0050\end{array}$ & $\begin{array}{l}1.0487 \\
0.0030\end{array}$ & $\begin{array}{l}1.0526 \\
0.0019\end{array}$ \\
\hline Sensorimotor cortex & 1.0489 & 1.0509 & 1.0515 & 1.0541 \\
\hline & $0 \cdot 0016$ & 0.0028 & 0.0015 & 0.0029 \\
\hline Caudate nucleus & 1.0503 & 1.0463 & 1.0480 & 1.0530 \\
\hline & 0.0014 & 0.0028 & 0.0010 & 0.0018 \\
\hline Occipital cortex & 1.0576 & 1.0533 & 1.0519 & 1.0491 \\
\hline & 0.0021 & 0.0012 & 0.0031 & 0.0006 \\
\hline
\end{tabular}




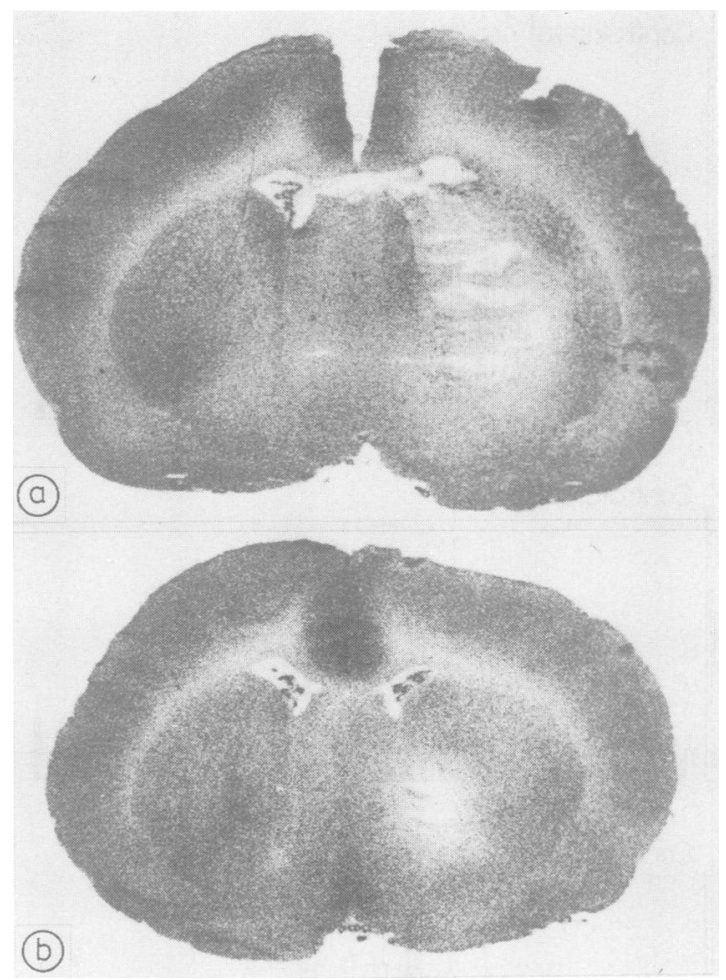

Fig 4 Autoradiograph at the level of the ipsilateral caudate nucleus in an animal receiving vehicle (a) and one receiving nimodipine (b). There is a reduction in $r C B F$ in the ipsilateral caudate nucleus in both animals but more so in the animal receiving vehicle. The pale area represents reduced regional cerebral blood flow. greater in the ipsilateral frontal cortex of the nimodipine group $(69,3.6 \mathrm{ml}$ reducing to $35,5.6 \mathrm{ml}$ $\left.100 \mathrm{~g}^{-1} \mathrm{~min}^{-1}\right)$ compared with the control group (51, $5.7 \mathrm{ml}$ reducing to $\left.42,11.5 \mathrm{ml} 100 \mathrm{~g}^{-1} \min ^{-1}\right)$. The reduction in $\mathrm{rCBF}$ was significant in the nimodipine group ( $\mathrm{p}<0.01$, unpaired $t$ test) but not in the vehicle group. The maximum reduction in $\mathrm{rCBF}$ in the ipsilateral frontal cortex of the nimodipine group occurred within 5 minutes following production of the intracerebral haemorrhage, while in the vehicle group maximum reduction in $\mathrm{rCBF}$ was not seen until 30 minutes. Following this period of maximum reduction, the $\mathrm{rCBF}$ on the ipsilateral side in both groups rose over the remainder of the experimental period but not significantly above resting values.

In the contralateral frontal cortex following a reduction in $\mathrm{rCBF}$ at the time of the intracerebral haemorrhage, the rCBF gradually rose again in both groups. At the end of the experimental period, rCBF in the contralateral frontal cortex was $63,7 \cdot 2 \mathrm{ml} 100$ $\mathrm{g}^{-1} \mathrm{~min}^{-1}$ in the nimodipine group and $56,7 \cdot 4 \mathrm{ml}$ $100 \mathrm{~g}^{-1} \mathrm{~min}^{-1}$ in the vehicle group.

\section{Measurement of $B B B$ permeability from the ${ }^{14} C \alpha A I B$ autoradiographs}

Table 8 shows the values of the capillary transfer constant $\left(\mathrm{K}_{1}\right)$ for ${ }^{14} \mathrm{C} \alpha$ AIB measured at 17 discrete neuroanatomically determined loci. In general the $\mathrm{K}_{1}$ values were higher in both contralateral and ipsilateral structures of the nimodipine group than in the vehicle group. The increase in $K_{1}$ was significant in the ipsilateral hippocampus of the nimodipine group $\left(7 \cdot 5,1.0 \mathrm{ml} \mathrm{g}^{-1} \mathrm{~min}^{-1} \times 10^{3}\right)$ compared with the vehicle group $\left(3 \cdot 6,0.3 \mathrm{ml} \mathrm{g}^{-1} \mathrm{~min}^{-1} \times 10^{3}\right)$, and

Table 6 Analysis of regional cerebral blood flow

\begin{tabular}{|c|c|c|c|c|}
\hline \multicolumn{5}{|c|}{21 areas measured bilaterally, $N=12:$ mean values, $S E M,\left(\mathrm{ml} 100 \mathrm{~g}^{-1} \mathrm{~min}^{-1}\right)$} \\
\hline & \multicolumn{2}{|c|}{ Nimodipine } & \multicolumn{2}{|l|}{ Vehicle } \\
\hline & Ipsilateral & Contralateral & Ipsilateral & Contralateral \\
\hline Frontal cortex & $166,22 \cdot 8$ & $150,31 \cdot 5$ & $121,15 \cdot 3$ & $117,29 \cdot 0$ \\
\hline Cingulate cortex & $178,38 \cdot 4$ & $146,25 \cdot 3^{*}$ & $131,22 \cdot 0$ & $96,12 \cdot 0^{*}$ \\
\hline \multicolumn{5}{|l|}{ Caudate nucleus } \\
\hline Anterior - High & $148,24 \cdot 2$ & $106,25 \cdot 0$ & $135,17 \cdot 4$ & $97,16 \cdot 0$ \\
\hline - Low & $126,15 \cdot 8$ & $70,17 \cdot 6^{*}$ & $114,13 \cdot 7$ & $41,11 \cdot 2^{*}$ \\
\hline Middle - - High & $141,10.9$ & $131,29 \cdot 3$ & $137,14.4$ & $87,20 \cdot 1$ \\
\hline - Low & $117,12 \cdot 2$ & $47,8 \cdot 9^{*}$ & $111,17 \cdot 0$ & $32,5 \cdot 1^{*}$ \\
\hline Posterior - High & $135,16.9$ & $122,20 \cdot 3$ & $135,15.5$ & $88,21 \cdot 3$ \\
\hline- Low & $88,10 \cdot 2$ & $60,15 \cdot 6$ & $93,15.4$ & $42,12 \cdot 8^{*}$ \\
\hline Hypothalamus & $114,11.9$ & $114,10 \cdot 3$ & $107,17 \cdot 3$ & $93,16 \cdot 7$ \\
\hline Sensorimotor cortex & $163,25 \cdot 8$ & $149,27 \cdot 3$ & $139,16 \cdot 8$ & $122,22 \cdot 1$ \\
\hline Parietal cortex & $199,45 \cdot 0$ & $209,68 \cdot 5$ & $127,20 \cdot 8$ & $127,25 \cdot 1$ \\
\hline Lateral geniculate & $154,43 \cdot 4$ & $144,35 \cdot 0$ & $124,26 \cdot 6$ & $114,24 \cdot 3$ \\
\hline Corpus callosum & $55,20 \cdot 5$ & $61,24 \cdot 4$ & $58,7 \cdot 6$ & $51,5 \cdot 6$ \\
\hline Hippocampus & $141,58 \cdot 0$ & $93,16.6$ & $106,15 \cdot 0$ & $114,20 \cdot 1$ \\
\hline Red nucleus & $118,13.0$ & $115,12 \cdot 7$ & $121,22 \cdot 5$ & $118,19 \cdot 3$ \\
\hline Superior colliculus & $143,19 \cdot 3$ & $147,18 \cdot 6$ & $147,14.6$ & $132,20 \cdot 5$ \\
\hline Visual cortex & $171,18 \cdot 3$ & $156,29.9$ & $157,30 \cdot 0$ & $174,44 \cdot 7$ \\
\hline Pons & $98,10.9$ & $90,9 \cdot 3$ & $85,9.0$ & $98,12 \cdot 8$ \\
\hline Cerebellum & $88,7 \cdot 7$ & $92,10 \cdot 1$ & $91,7 \cdot 2$ & $86,10 \cdot 0$ \\
\hline
\end{tabular}

*significant side-to side difference between structures in the same group

$\mathrm{p}<0.05$ Unpaired $t$ test 

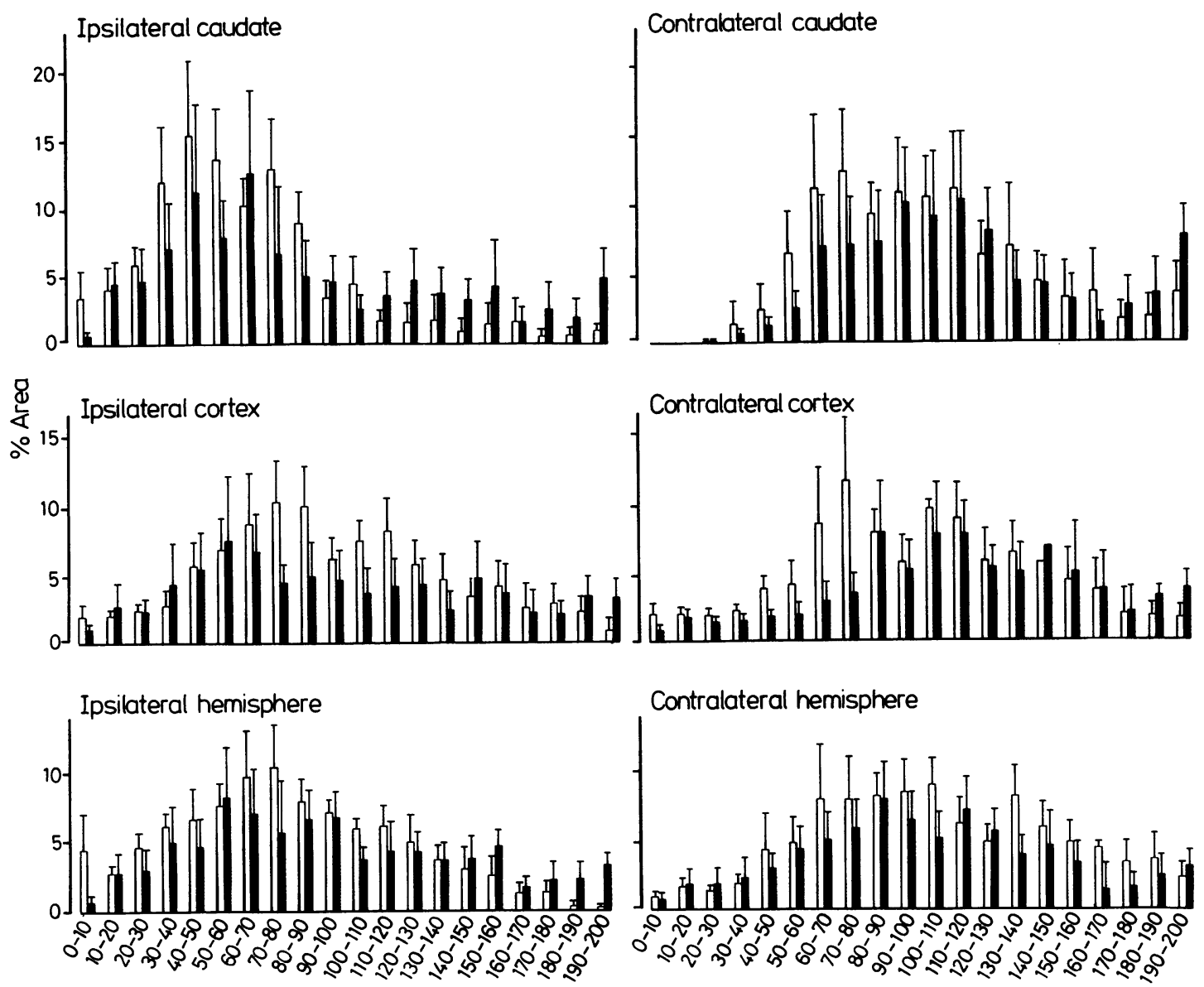

Fig 5 Percentage of caudate nucleus, cerebral hemisphere, and cerebral cortex having an rCBF within the stated limits. Flows are in $\mathrm{ml} 100 \mathrm{~g}^{-1} \mathrm{~min}^{-1}$ in flow ranges of $10 \mathrm{ml} 100 \mathrm{~g}^{-1} \mathrm{~min}^{-1}$. Open bars represent vehicle treated animals, while black bars represent nimodipine treated animals.

also in the contralateral hippocampus of the nimodipine group $\left(6.9,1.4 \mathrm{ml} \mathrm{g}{ }^{-1} \min ^{-1} \times 10^{3}\right)$ compared with the vehicle group $\left(3.5,0.2 \mathrm{ml} \mathrm{gm}^{-1}\right.$ $\left.\min ^{-1} \times 10^{3}\right)(\mathrm{p}<0.01$, Scheffe test $)$.

\section{Discussion}

Animals in this experimental series were pre-treated with either nimodipine $\left(1 \mu \mathrm{g} \mathrm{kg}^{-1} \mathrm{~min}^{-1}\right)$ or vehicle prior to the production of the intracerebral haemorrhage. Although the relevance of pretreatment may be questioned, we believe that there are clinical situations in which pre-treatment is possible. Evidence from several animal models of cerebral ischaemia suggests that the residual cerebral blood flow following the onset of ischaemia is important in determining the degree of ischaemic damage. ${ }^{28-32}$ Increasing the $\mathrm{rCBF}$ after the onset of ischaemia may therefore prevent the development of further ischaemic damage in the penumbra zone. Several authors have reported that nimodipine is capable of maintaining $\mathrm{rCBF}$ following cerebrovascular occlusion and of preventing the occurrence of delayed hypoperfusion. ${ }^{153334}$ Steen $^{3536}$ in a canine model reported a significant increase in cerebral blood flow in animals treated with nimodipine either before or immediately following 10 minutes of complete cerebral ischaemia, when compared with controls. Following restoration of the cerebral circulation, repeated measurements of cerebral blood flow were made for up to 2 hours. Cerebral blood flow in the animals receiving nimodipine remained significantly higher than in the controls. Assessment of the dogs neurologically 48 hours following the ischaemic episode revealed a significant improvement in the neurological outcome in the group pre-treated with 
Table 7 Regional cerebral blood flow in frontal cortex measured using $\mathrm{H}^{+}$clearance $\left(N=12:\right.$ mean values, SEM $\left.\left(\mathrm{ml} 100 \mathrm{~g}^{-1} \mathrm{~min}^{-1}\right)\right)$

\begin{tabular}{|c|c|c|c|c|}
\hline & \multicolumn{2}{|l|}{ Vehicle } & \multicolumn{2}{|c|}{ Nimodipine } \\
\hline & $\begin{array}{l}\text { Contra- } \\
\text { lateral }\end{array}$ & $\begin{array}{l}\text { Ipsi- } \\
\text { lateral }\end{array}$ & $\begin{array}{l}\text { Contra- } \\
\text { lateral }\end{array}$ & $\begin{array}{l}\text { Ipsi- } \\
\text { lateral }\end{array}$ \\
\hline $\begin{array}{l}\text { Resting } \\
30 \text { min infusion } \\
5 \text { min post }\end{array}$ & $\begin{array}{l}56,6 \cdot 6 \\
66,6 \cdot 5^{*}\end{array}$ & $\begin{array}{l}66,9 \cdot 1 \\
69,3 \cdot 6^{*}\end{array}$ & $\begin{array}{l}54,3 \cdot 4 \\
49,3 \cdot 8\end{array}$ & $\begin{array}{l}55,4 \cdot 9 \\
51,5 \cdot 7\end{array}$ \\
\hline $\begin{array}{l}\text { haematoma } \\
30 \mathrm{~min} \\
60 \mathrm{~min} \\
90 \mathrm{~min} \\
120 \mathrm{~min} \\
150 \mathrm{~min} \\
180 \mathrm{~min} \\
210 \mathrm{~min} \\
240 \mathrm{~min}\end{array}$ & $\begin{array}{l}57,2 \cdot 5 \\
56,7 \cdot 4 \\
65,9 \cdot 2 \\
59,6 \cdot 9 \\
62,5 \cdot 9 \\
57,6 \cdot 7 \\
61,5 \cdot 1 \\
61,5 \cdot 4 \\
63,7 \cdot 2\end{array}$ & $\begin{array}{l}35,5 \cdot 6 \dagger \\
39,5 \cdot 0 \\
46,8 \cdot 4 \\
47,4 \cdot 2 \\
51,4 \cdot 6 \\
50,3 \cdot 9 \\
53,3 \cdot 9 \\
47,3 \cdot 1 \\
54,3 \cdot 3\end{array}$ & $\begin{array}{l}36,7 \cdot 2 \\
40,7 \cdot 2 \\
43,7 \cdot 2 \\
46,7 \cdot 5 \\
47,6 \cdot 8 \\
50,8 \cdot 5 \\
50,6 \cdot 7 \\
59,7 \cdot 6 \\
56,7 \cdot 4\end{array}$ & $\begin{array}{l}42,11 \cdot 5 \\
33,2 \cdot 7 \\
40,7 \cdot 6 \\
46,12 \cdot 8 \\
51,14 \cdot 4 \\
46,7 \cdot 5 \\
51,10 \cdot 9 \\
56,9 \cdot 5 \\
53,6 \cdot 0\end{array}$ \\
\hline
\end{tabular}

†Significant difference when compared with the corresponding previous value in the same side, same group.

$\mathrm{p}<0.01$ (unpaired $t$ test)

* Significant difference between the groups.

$\mathrm{p}<0.05$ (unpaired $t$ test)

nimodipine when compared to the control group. However, in the group given nimodipine in the postischaemic period the results were equivocal. ${ }^{36} \mathrm{~A}$ further series of experiments using a primate model of complete cerebral ischaemia ${ }^{37}$ showed that nimodipine initiated in the post-ischaemic period significantly improved neurological outcome at 96 hours when compared with a control group.

Our choice of $1 \mu \mathrm{g} \mathrm{kg}^{-1} \mathrm{~min}^{-1}$ is based on previous work in this laboratory ${ }^{12}$ indicating that this was the optimum dosage to reduce ischaemic damage, in a rat model, of focal cerebral ischaemia. Mohamed et al ${ }^{12}$ showed that higher dosages of nimodipine led to an elevated plasma glucose and fall in the mean arterial blood pressure (MABP), and would therefore be unlikely to give additional benefits by virtue of increased cerebral blood flow. The transient fall in the MABP following infusion of nimodipine, in the present study, was of similar degree to that reported by other authors ${ }^{121438}$ as was the rise in the plasma arterial concentration of glucose.

Although we used a constant volume of blood $(100 \mu \mathrm{l})$, introduced at a standard pressure (100 $\mathrm{mmHg}$ ), there was some variability in the configuration of the resulting haematomas. The size and extent of the lesions were similar to those reported by Nath et al, using $100 \mu \mathrm{l}$ of blood in a similar model. ${ }^{7}$ The variation in configuration of the haematomas may have been responsible for the variability in rCBF values measured in the different loci from animal to animal. Nevertheless, measurement of rCBF from the ${ }^{14} \mathrm{C}$ IAP autoradiographs 4 hours after the insult showed a distinct trend for animals pre-treated with nimodipine to have higher $\mathrm{rCBF}$ values ipsilaterally and contralaterally than those receiving vehicle. The difference in $\mathrm{CCBF}$ between the two groups was most marked in the ipsilateral caudate nucleus in areas of low flow, although $\mathrm{rCBF}$ was reduced in both groups ipsilaterally compared with the contralateral side. The reduction in $\mathrm{rCBF}$ was attenuated in those animals receiving nimodipine compared with those receiving vehicle. These findings are in keeping with those of other authors ${ }^{33-36}$ who reported that the occurrence of delayed hypoperfusion following various periods of ischaemia in animal models was either reduced in severity or abolished following the administration of nimodipine. This reduction of delayed hypoperfusion may be due to the direct effect of nimodipine on the cerebral blood vessels, as was suggested by Haws. ${ }^{39}$

Table 8 Analysis of capillary transfer constant $\left(K_{1}\right)$ for $14 C$ - AIB areas measured bilaterally $\left(N=12:\right.$ mean values, $\operatorname{SEM}\left(\mathrm{ml} \mathrm{g}^{-1} \min ^{-1} \times 10^{3}\right)$

\begin{tabular}{|c|c|c|c|c|}
\hline \multirow[b]{2}{*}{ Brain region } & \multicolumn{2}{|l|}{ Nimodipine } & \multicolumn{2}{|l|}{ Vehicle } \\
\hline & Contralateral & Ipsilateral & Contralateral & Ipsilateral \\
\hline \multirow{2}{*}{$\begin{array}{l}\text { Frontal cortex } \\
\text { Cingulate cortex } \\
\text { Caudate nucleus }\end{array}$} & $4 \cdot 5,0 \cdot 3$ & $4 \cdot 7,0 \cdot 6$ & $3 \cdot 4,0.2$ & $3 \cdot 9,0 \cdot 2$ \\
\hline & $4 \cdot 0,0.6$ & $4 \cdot 1,0 \cdot 5$ & $3 \cdot 7,0 \cdot 3$ & $3 \cdot 8,0 \cdot 2$ \\
\hline \multirow{2}{*}{$\begin{array}{c}\text { Anterior - High } \\
\text { - Low }\end{array}$} & $3 \cdot 3,0 \cdot 4$ & $5 \cdot 0,0 \cdot 8$ & $3 \cdot 4,0 \cdot 2$ & $5 \cdot 0,0 \cdot 5$ \\
\hline & $3 \cdot 3,0.5$ & $4 \cdot 0,0 \cdot 5$ & $3 \cdot 4,0 \cdot 2$ & $3 \cdot 7,0 \cdot 2$ \\
\hline Middle - - High & $3.6,0.4$ & $5 \cdot 9,1 \cdot 2$ & $3 \cdot 1,0 \cdot 1$ & $5 \cdot 0,0.4$ \\
\hline -Low & $3.5,0.4$ & $4 \cdot 5,0.9$ & $3 \cdot 2,0.2$ & $4 \cdot 3,0.4$ \\
\hline Posterior - High & $3.2,0.4$ & $5 \cdot 3,0 \cdot 8$ & $3 \cdot 2,0 \cdot 2$ & $4 \cdot 6,0 \cdot 5$ \\
\hline -Low & $3 \cdot 3,0.4$ & $3 \cdot 5,0 \cdot 3$ & $3 \cdot 1,0 \cdot 1$ & $4 \cdot 2,0.4$ \\
\hline Hypothalamus & $4 \cdot 0,0 \cdot 4$ & $3.9,0.5$ & $3 \cdot 4,0 \cdot 2$ & $4 \cdot 8,1 \cdot 1$ \\
\hline Sensorimotor cortex & $4 \cdot 0,0 \cdot 2$ & $3 \cdot 9,0 \cdot 3$ & $3 \cdot 4,0 \cdot 2$ & $3 \cdot 8,0 \cdot 3$ \\
\hline Parietal cortex & $4 \cdot 2,0 \cdot 3$ & $3.9,0.4$ & $8 \cdot 6,4 \cdot 7$ & $8 \cdot 8,4 \cdot 2$ \\
\hline Thalamus & $3 \cdot 6,0 \cdot 4$ & $3 \cdot 5,0 \cdot 4$ & $3 \cdot 4,0 \cdot 2$ & $3 \cdot 8,0 \cdot 5$ \\
\hline Hippocampus & $6.9,1.4 \dagger$ & $7 \cdot 5,1.0 \dagger$ & $3 \cdot 5,0 \cdot 2$ & $3 \cdot 6,0 \cdot 3$ \\
\hline Superior colliculus & $6 \cdot 7,2 \cdot 2$ & $5 \cdot 0,1 \cdot 6$ & $3 \cdot 6,0 \cdot 2$ & $3 \cdot 5,0 \cdot 1$ \\
\hline Visual cortex & $4 \cdot 1,0 \cdot 2$ & $3 \cdot 8,0 \cdot 4$ & $3 \cdot 4,0 \cdot 2$ & $3 \cdot 6,0 \cdot 3$ \\
\hline Pons & $3.9,0.6$ & $3 \cdot 9,0 \cdot 4$ & $3 \cdot 3,0 \cdot 2$ & $3 \cdot 5,0 \cdot 2$ \\
\hline Cerebellum & $3.4,0.4$ & $3 \cdot 5.0 \cdot 4$ & $3 \cdot 4,0 \cdot 2$ & $3 \cdot 4,0 \cdot 2$ \\
\hline
\end{tabular}

$+p<0.01$ (Scheffe test).

tsignificant difference between the same side in both groups 


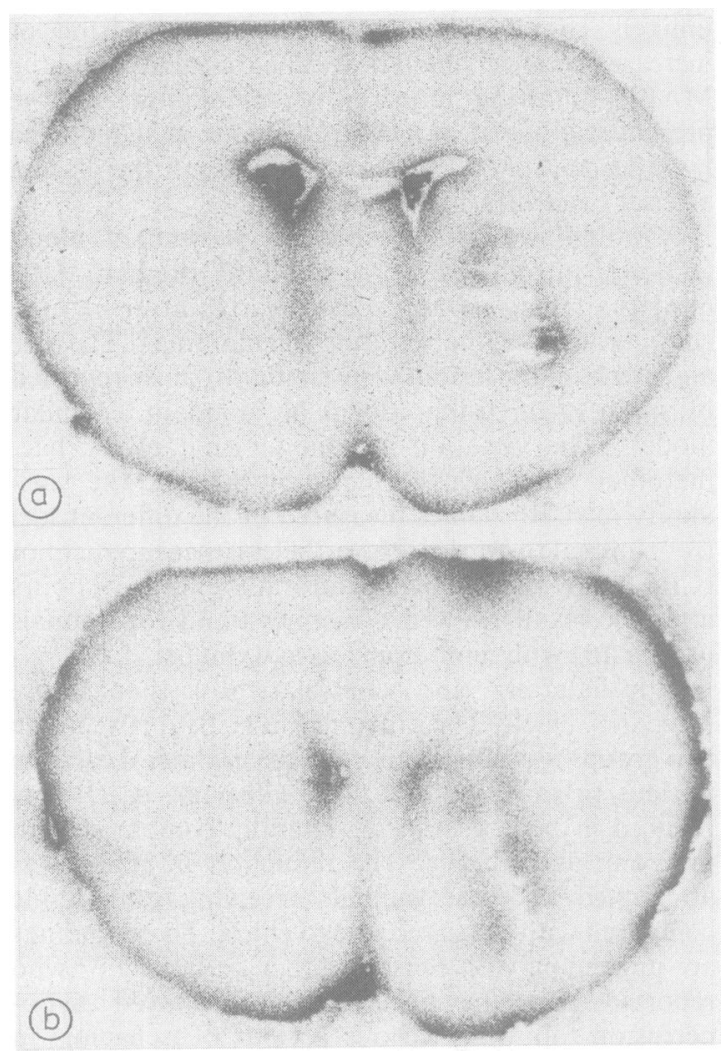

Fig 6 Typical appearance of an autoradiograph obtained using ${ }^{14} C-\alpha$ AIB. Naked eye appearances are similar in both the vehicle treated $(a)$ and nimodipine (b).

In addition to measuring rCBF using autoradiographic techniques, it was possible using the $\mathrm{H}^{+}$ clearance technique to obtain serial rCBF measurements from the overlying frontal cortex. The significant rise in rCBF seen following infusion of nimodipine is in keeping with the finding of other authors. ${ }^{10-12}$ Surprisingly, following production of the intracerebral haemorrhage there was a significant reduction in the $\mathrm{rCBF}$ in the ipsilateral frontal cortex of the nimodipine group ( $\mathrm{p}<0.01$, unpaired $t$ test) but not in the vehicle group. This may have been due to an "inserve steal" phenomenon ${ }^{3840}$ in the nimodipine group, whereby rCBF in underperfused areas (that is the ipsilateral caudate nucleus) is preserved at the expense of $\mathrm{rCBF}$ in relatively normal areas where CBF was measured with $\mathrm{H}_{2}$ clearance (in this case, the ipsilateral frontal cortex). Alternatively, the reduction in $\mathrm{rCBF}$ may appear greater in the nimodipine group because the rCBF prior to the production of the haematoma was higher than in the vehicle group.

Following the significant reduction in $\mathrm{rCBF}$ in the ipsilateral frontal cortex of the nimodipine group (maximum at 5 minutes), $\mathrm{rCBF}$ rose rapidly compared to that of the vehicle group (maximum reduction at 30 minutes), suggesting that nimodipine prevented the occurrence of delayed hypoperfusion. Steen ${ }^{3536}$ pointed out that the hypoperfusion state generally starts 15 to 30 minutes after the ischaemic episode. This would be supported by the maximum reduction in $\mathrm{rCBF}$ values in the vehicle group occurring 30 minutes following production of the haematoma.

The changes in intracranial pressure (ICP) following production of the intracerebral haemorrhage were of similar magnitude to those reported previously. ${ }^{6}$ Both $\mathrm{Gaab}^{40}$ and Guggiani ${ }^{41}$ have previously suggested that nimodipine may elevate ICP by virtue of its capacity to increase rCBF. However, their studies were performed on patients who had sustained severe head injuries and the ICP was measured using epidural pressure transducers rather than directly from the lateral ventricle, as in our series. There was not a significant difference in the ICP between the two groups at any time during the course of the experiments.

The trend for the nimodipine animals to have higher $\mathrm{rCBF}$ values was complemented by a reduction in the volume of pathological ischaemic damage seen in the ipsilateral caudate nucleus (especially anteriorly) in the nimodipine group compared to the vehicle group. A similar reduction in the amount of pathological ischaemic damage has recently been reported by us using a $50 \mu \mathrm{l}$ model of intracerebral haemorrhage. ${ }^{42}$ Nimodipine is thought to be capable of reducing the amount of ischaemic damage by acting in two ways: firstly, by relaxing the smooth muscle of the cerebral vasculature, vessel diameter is increased with a resulting increase in $\mathrm{rCBF}$ thereby preventing the occurrence of delayed hypoperfusion. ${ }^{1012}$ The second possibility, a blockage of the entry of $\mathrm{Ca}^{2+}$ into ischaemic cells and hence the prevention of the metabolic cascade that would be initiated in areas of ischaemia, remains speculative. ${ }^{43}$

There was not a significant difference in the brain specific gravity (SG) measurements between the two groups of animals. Most of the ischaemic damage and reduction in $\mathrm{rCBF}$ values were confined to the ipsilateral caudate nucleus, $\mathrm{rCBF}$ in other areas being above levels sufficient to cause ischaemia and hence oedema formation. The ipsilateral caudate nucleus was occupied mainly by the intracerebral haematoma, and tissue from this area may have been heavier due to extravasated protein from the haematoma, ${ }^{44}$ thereby masking any reduction in specific gravity due to oedema formation.

The increase in $\mathrm{K}_{1}$ of ${ }^{14} \mathrm{C} \alpha$ AIB may indicate an increase in BBB permeability in the group receiving nimodipine, or may reflect the fact that the amount of 
ischaemic damage was less in this group, a greater amount of functioning tissue being available to take up the ${ }^{14} \mathrm{C} \alpha \mathrm{AIB}$. The value of $\mathrm{K}_{1}$ depends on several factors; ${ }^{45}$ these include the permeability coefficient of ${ }^{14} \mathrm{C} \alpha \mathrm{AIB}$, the surface area of the brain capillaries, the distribution volume of the test material in the blood, and the velocity of blood flow. Under normal circumstances ${ }^{14} \mathrm{C} \alpha \mathrm{AIB}$ exchanges slowly across capillaries and the BBB permeability can be equated to the $K_{1}$ in the following manner: ${ }^{45}$

$$
\mathrm{PS}=-\mathrm{F} \ln \left[1-\left(\mathrm{K}_{1} / \mathrm{F}\right)\right.
$$

where PS is the product of the permeability and surface area of the capillaries, and $F$ is the blood flow. In our experiments $\mathrm{K}_{1} / \mathrm{F}$ was small $(<0.01)$ and therefore $P S=K_{1}$. Using this theoretical model with the range of $\mathrm{rCBF}$ values recorded in our experiments, analysis of the data showed that the increase in $K_{1}$ seen in the nimodipine group cannot be explained solely by the greater rCBF. Some other factor must be responsible, possibly increased uptake in the nimodipine group due to preservation of functioning tissue.

In conclusion, our experiments have shown that following an intracerebral haemorrhage pretreatment with nimodipine tended to attenuate the reduction in CBF that was seen at 4 hours, especially in the vicinity of the haematoma, and to reduce the amount of ischaemic damage. These findings suggest further experimental studies are indicated using nimodipine following the production of an intracerebral haemorrhage, particularly if the variability can be reduced. Nimodipine may also be of benefit following subarachnoid haemorrhage from ruptured intracranial aneurysms when it would be possible to effectively "pre-treat" the patient prior to the onset of delayed cerebral vasospasm, the aim being to maintain cerebral blood flow and thereby reduce the incidence of delayed cerebral ischaemia, as suggested previously from animal ${ }^{1819}$ and human studies. ${ }^{1617}$ Furthermore, such pretreatment may protect the brain if a further haemorrhage occurs before its cause can be treated surgically.

\section{References}

1 Arana-Iniguez R, Wilson E, Bastarnica E, Medici M. Cerebral haematomas. Surg Neurol 1976;6:45-52.

2 Lazorthes G. Surgery of cerebral haemorrhage: report on the results of 52 surgically treated cases. $J$ Neurosurg 1959;16: 355-64.

3 McKissock W, Richardson A, Taylor J. Primary intracerebral haemorrhage: A controlled trial of surgical and conservative treatment in 180 unselected cases. Lancet 1961;ii:221-6.

4 Richardson A. Surgical therapy of spontaneous intracerebral haemorrhage. Prog Neurol Surg 1969;3:397-418 (Basel: Karger and Chicago: Year Book).

5 Wheelock B, Weir B, Watts R, et al. Timing of surgery for intra- cerebral hematomas due to aneurysm rupture. $J$ Neurosurg 1983;58:476-81.

6 Bullock R, Mendelow AD, Teasdale GM, et al. Intracranial haemorrhage induced at arterial pressure in the rat. Part 1: Description of technique, ICP changes and neuropathological findings. Neurol Res 1984;6:184-188.

7 Nath FP, Kelly PT, Jenkins A, et al. Experimental intracerebral haemorrhage: Effects on blood flow, capillary permeability and histochemistry. J Neurosurg 1987;66:555-62.

8 Mendelow AD, Bullock R, Teasdale GM, et al. Intracranial haemorrhage induced at arterial pressure in the rat. Part 2: Short term changes in local cerebral blood flow measured by autoradiography. Neurol Res 1984;6:189-193.

9 Mizukami M, Tazawa T. Theoretical background for surgical treatment in hypertensive intracerebral haemorrhage. In: Mizukami M, Kamaya $\mathrm{H}$, Kogure $\mathrm{K}$, eds. Hypertensive Intracerebral Haemorrhage. New York: Raven Press, 1983:239-47.

10 Harper AM, Craigen L, Kazda S. Effect of the calcium antagonist Nimodipine on cerebral blood flow and metabolism in the primate. J Cereb Blood Flow Metab 1981;1:349-56.

11 Haws CW, Gourley JK, Heistad DD. Effects of nimodipine on cerebral blood flow. J Pharmacol Exp Therap 1983;225:24-8.

12 Mohamed AA, Mendelow AD, Graham DI, et al. The effect of nimodipine on local cerebral blood flow, glucose use and focal cerebral ischaemia using autoradiographic techniques. In: Betz E, Deck K, Hoffmeister F, eds. Nimodipine-Pharmacological and Clinical Properties. Stuttgart: Schattauer Verlag, 1985: 105-12.

13 Hoffmeister F, Kazda S, Krause HP. Influence of nimodipine (Bay e 9736) on the post-ischaemic changes of brain function. Acta Neurol Scand 1979;(suppl 72):358-9.

14 Mohamed AA, Gotoh O, Graham DI, et al. Effect of pretreatment with the calcium antagonist nimodipine on local cerebral blood flow and histopathology after middle cerebral artery occlusion. Ann Neurol 1985;18:705-11.

15 Kazda S, Hoffmeister F, Garthoff B, et al. Prevention of the post-ischaemic impaired reperfusion of the brain by nimodipine. Acta Neurol Scand 1979;(suppl 72):302-3.

16 Allen GS, Ahn HS, Preziosi TJR, et al. Cerebral arterial spasm-a controlled trial of nimodipine in patients with subarachnoid haemorrhage. $N$ Engl J Med 1983;308:619-24.

17 Auer LM. Acute operation and preventive nimodipine improve outcome in patients with ruptured cerebral aneurysms. Neurosurgery 1984:15:57-66.

18 Espinosa F, Weir B, Overton T, et al. A randomised placebocontrolled double-blind trial of nimodipine after SAH in monkeys. Part 1: Clinical and radiological findings. J Neurosurg 1984;60:1167-75.

19 Gioia AE, White RP, Bakhtian B, et al. Evaluation of the efficacy of intrathecal nimodipine in canine models of chronic cerebral vasospasm. J Neurosurg 1985;62:721-8.

20 Sinar EJ, Mendelow AD, Graham DI, et al. Experimental intracerebral haemorrhage: effects of a temporary mass lesion. J Neurosurg 1987;66:568-76.

21 Brierley JB, Meldrum BS, Brown AW. The threshold and neuropathology of cerebral "anoxic-ischaemic" cell change. Arch Neurol 1973;29:367-73.

22 Brown AW, Brierley JB. The nature, distribution and earliest stages of anoxic-ischaemic nerve cell damage in the rat brain as defined by the optical microscope. Br J Exp Pathol 1968;XLIX:87-106.

23 Konig J, Klippel RA. The Rat Brain. Baltimore: Williams and Wilkins, 1963.

24 Haining JL, Turner MD, Pantall RM. Measurement of local cerebral blood flow in the unanaesthetised rat using a hydrogen clearance method. Circulation Res 1968;23:313-23.

25 Shigeno T, Brock M, Shigeno S, et al. The determination of brain water content: Microgravimetry versus drying-weighing methods. J Neurosurg 1982;57:99-107.

26 Sakurada O, Kennedy C, Jehle J, Brown JD, Carbin GL, Sokoloff 
L. Measurement of local cerebral blood flow with iodo $\left[{ }^{14} \mathrm{c}\right]$ antipyrine. Am J Physiol 1978;234:H59-H66.

27 Blasberg RG, Fenstermacher JD, Patlak CS. Transport of alphaaminoisobutyric acid across brain capillary and cellular membranes. J Cereb Blood Flow Metab 1983;3:8-32.

28 Symon L, Crockard HA, Dorsch NWC, et al. Local cerebral blood flow and vascular reactivity in a chronic stable stroke in baboons. Stroke 1975;6:482-92.

29 Symon L, Brierley JB. Morphological changes in cerebral blood vessels in chronic ischemic infarction: Flow correlation obtained by the hydrogen clearance method. In: CervosNavarro J, Betz E, Matakas F, et al, eds. The Cerebral Vessel Wall. New York: Raven Press, 1976;165-74.

30 Astrup J, Siesjo BK, Symon L. Thresholds in cerebral ischemiathe ischemic penumbra. Stroke 1981;12:723-5.

31 Astrup J. Energy-requiring cell functions in the ischemic brain: Their critical supply and possible inhibition in protective therapy. $J$ Neurosurg 1982;56:482-97.

32 Marcoux FW, Morawetz RB, Crowell RM, et al. Regional vulnerability and selective necrosis in experimental focal cerebral ischemia. Reivich M, Hurtig HI, eds. Cerebrovascular Diseases. New York: Raven Press, 1983:213-221.

33 Smith M-L, Kagstrom E, Rosen I, et al. Effect of the calcium antagonist nimodipine on the delayed hypoperfusion following incomplete ischemia in the rat. J Cereb Blood Flow Metab 1983;3:543-6.

34 Kazda S, Towart R. Nimodipine: a new calcium antagonist drug with a preferential cerebrovascular action. Acta Neurochirurgica 1982;63:259-65.

35 Steen PA, Newberg LA, Milde JH, et al. Nimodipine improves cerebral blood flow and neurologic recovery after complete cerebral ischemia in the dog. J Cereb Blood Flow Metab 1983;3:38-43.
36 Steen PA, Newberg LA, Milde JH, et al. Cerebral blood flow and neurologic outcome when nimodipine is given after complete cerebral ischemia in the dog. J Cereb Blood Flow Metab 1984;4:82-87.

37 Steen PA, Gisvold SE, Milde JH, et al. Nimodipine improves outcome when given after complete cerebral ischemia in primates. Anaesthesiology 1985;62:406-14.

38 Gelmers HJ. Effect of nimodipine (Bay e 9736) on post-ischaemic cerebrovascular reactivity, as revealed by measuring regional cerebral blood flow (rCBF). Acta Neurochirurgica 1982:63:283-90.

39 Haws CW, Heistad DD. Effects of nimodipine on cerebral vasoconstrictor responses. Am J Physiol 1984;247:H170-6.

40 Gaab MR, Brawanski A, Bockhorn J, et al. Calcium antagonism A new therapeutic principle in stroke and cerebral vasospasm. rCBF Bull 1982;3:47-51.

41 Guggiani M, Guillaume A, Dagreou F, et al. Intracranial pressure (ICP) and haemodynamic effects of a new calcium blocking agent: Nimodipine. Anaesthesiology 1983;59:A357.

42 Sinar EJ, Mendelow AD, Graham DI, et al. Intracerebral haemorrhage: The effect of pretreatment with nimodipine on the volume of ischaemic damage. J Cereb Blood Flow Meta. 1987;7, (Suppl 1):S158.

43 Glossman H, Goll A, Rombusch M, Ferry DR. Molecular pharmacology of $\mathrm{Ca}^{2+}$ channels: Receptor binding studies. In: Betz E, Deck K, Hoffmeister F, eds. Nimodipine Pharmacological and Clinical Properties. Stuttgart: Schattauer Verlag, 1985:57-73.

44 Marmarou A, Tanaka K, Shulman K. An improved gravimetric measure of cerebral oedema. J Neurosurg 1982;56:246-53.

45 Blasberg RG. Problems of quantifying effects of microwave irradiation on the blood-brain barrier. $J$ Radio Science 1979:14:65:335-44. 


\section{Correction}

In the article by Sinar E J, Mendelow A D, Graham D I, Teasdale G M. Experimental intracerebral haemorrhage: the effect of nimodipine pretreatment (J Neurol Neurosurg Psychiatry 1988;51:651-62) there were important errors in tables 2 and 6. Table 2 should have been as follows:

Table 2 Physiological variables in the two groups $(N=48$ : mean values, $S E M)$

\begin{tabular}{|c|c|c|c|c|c|c|}
\hline & \multicolumn{2}{|l|}{ Arterial pH } & \multicolumn{2}{|c|}{ Arterial $\mathrm{PaO}_{2} \mathrm{mmHg}$} & \multicolumn{2}{|c|}{ Arterial $\mathrm{PaCO}_{2} \mathrm{mmHg}$} \\
\hline & Nimodipine & Vehicle & Nimodipine & Vehicle & Nimodipine & Vehicle \\
\hline \multirow[t]{3}{*}{$\begin{array}{l}\text { Resting } \\
\text { Infusion for } 30 \text { minutes } \\
5 \mathrm{~min} \text { post haemorrhage } \\
30 \mathrm{~min} \\
60 \mathrm{~min} \\
90 \mathrm{~min} \\
120 \mathrm{~min} \\
150 \mathrm{~min} \\
180 \mathrm{~min} \\
210 \mathrm{~min} \\
240 \mathrm{~min}\end{array}$} & $\begin{array}{l}7.424,0.007 \\
7.428,0.014 \\
7.434,0.009 \\
7.429,0.009 \\
7.438,0.012 \\
7.441,0.013 \\
7.400,0.020 \\
7.399,0.021 \\
7.434,0.013 \\
7.426,0.009 \\
7.431,0.014\end{array}$ & $\begin{array}{l}7.420,0.022 \\
7.407,0.035 \\
7.462,0.018 \\
7.448,0.020 \\
7.438,0.019 \\
7.436,0.026 \\
7.436,0.022 \\
7.459,0.025 \\
7.463,0.012 \\
7.457,0.013 \\
7.440,0.012\end{array}$ & $\begin{array}{l}145 \cdot 9,7 \cdot 7 \\
148 \cdot 5,7 \cdot 0 \\
160 \cdot 0,5 \cdot 6 \\
162 \cdot 6,6 \cdot 1 \\
162 \cdot 8,5 \cdot 2 \\
160 \cdot 7,4 \cdot 2 \\
163 \cdot 2,4 \cdot 9 \\
170 \cdot 2,5 \cdot 9 \\
169 \cdot 5,7 \cdot 4 \\
144 \cdot 2,8 \cdot 2 \\
161 \cdot 7,8 \cdot 6\end{array}$ & $\begin{array}{l}140 \cdot 2,12 \cdot 2 \\
137 \cdot 2,9 \cdot 2 \\
151 \cdot 6,7 \cdot 3 \\
144 \cdot 7,6 \cdot 6 \\
141 \cdot 0,10 \cdot 5 \\
145 \cdot 9,6 \cdot 8 \\
147 \cdot 5,9 \cdot 2 \\
146 \cdot 7,8 \cdot 2 \\
148 \cdot 0,6 \cdot 2 \\
140 \cdot 6,8 \cdot 4 \\
145 \cdot 4,4 \cdot 4\end{array}$ & $\begin{array}{l}38 \cdot 9,0 \cdot 4 \\
37 \cdot 7,0 \cdot 7 \\
37 \cdot 6,0 \cdot 8 \\
38 \cdot 5,0 \cdot 5 \\
37 \cdot 6,0 \cdot 6 \\
37 \cdot 2,0 \cdot 7 \\
37 \cdot 3,0 \cdot 8 \\
36 \cdot 6,0 \cdot 4 \\
37 \cdot 7,0 \cdot 5 \\
36 \cdot 6,0 \cdot 5 \\
37 \cdot 0,0 \cdot 3\end{array}$ & $\begin{array}{l}37 \cdot 1,0.9 \\
36 \cdot 6,1 \cdot 1 \\
37 \cdot 6,0 \cdot 5 \\
37 \cdot 7,0.6 \\
38 \cdot 0,0.8 \\
37 \cdot 9,0.7 \\
36 \cdot 8,0 \cdot 8 \\
36 \cdot 6,0.6 \\
36 \cdot 9,0.6 \\
36 \cdot 8,0 \cdot 3 \\
37 \cdot 6,0.3\end{array}$ \\
\hline & \multicolumn{2}{|c|}{ Mean Arterial BPmmHg } & \multicolumn{2}{|c|}{$\begin{array}{l}\text { Arterial Plasma } \\
\text { Glucose mmol/l }\end{array}$} & \multicolumn{2}{|c|}{ Arterial Haematocrit \% } \\
\hline & Nimodipine & Vehicle & Nimodipine & Vehicle & Nimodipine & Vehicle \\
\hline $\begin{array}{l}\text { Resting } \\
\text { Infusion for } 30 \text { minutes } \\
5 \mathrm{~min} \text { post haemorrhage } \\
30 \mathrm{~min} \\
60 \mathrm{~min} \\
90 \mathrm{~min} \\
120 \mathrm{~min} \\
150 \mathrm{~min} \\
180 \mathrm{~min} \\
210 \mathrm{~min} \\
240 \mathrm{mins}\end{array}$ & $\begin{array}{l}98 \cdot 3,1 \cdot 4 \\
92 \cdot 2,3 \cdot 5^{*} \\
93 \cdot 6,3 \cdot 2^{*} \\
101 \cdot 5,8 \cdot 3 \\
111.5,6 \cdot 3 \\
111 \cdot 0,5 \cdot 7 \\
109 \cdot 7,4 \cdot 0 \\
107 \cdot 2,2 \cdot 0 \\
99 \cdot 3,2 \cdot 0 \\
95 \cdot 8,1 \cdot 7 \\
97 \cdot 5,1 \cdot 3\end{array}$ & $\begin{array}{r}95 \cdot 8,3 \cdot 7 \\
100 \cdot 6,4 \cdot 2 \\
101 \cdot 8,3 \cdot 9 \\
100 \cdot 0,1 \cdot 9 \\
99 \cdot 3,2 \cdot 8 \\
97 \cdot 5,3 \cdot 5 \\
102 \cdot 5,4 \cdot 1 \\
105 \cdot 2,3 \cdot 7 \\
103 \cdot 8,1 \cdot 8 \\
97 \cdot 7,0 \cdot 7 \\
94 \cdot 5,1 \cdot 8\end{array}$ & $\begin{array}{l}9.8,0.4 \\
11 \cdot 6,0.3 \dagger \\
11 \cdot 2,0.4 \dagger \\
11 \cdot 4,0.2 \dagger \\
11 \cdot 2,0.6 \\
11 \cdot 2,0.5 \\
11 \cdot 3,0.6 \\
11 \cdot 3,0.5 \\
10.9,0.5 \\
10.8,0.4 \dagger \\
10.9,0.4 \dagger\end{array}$ & $\begin{array}{l}9 \cdot 8,0.3 \\
9 \cdot 1,0.5 \\
9 \cdot 4,0.4 \\
9 \cdot 1,0.4 \\
9 \cdot 3,0.3 \\
9 \cdot 7,0.5 \\
8 \cdot 9,0.3 \\
9 \cdot 2,0.5 \\
9 \cdot 6,0.4 \\
9 \cdot 2,0.2 \\
9 \cdot 0,0.2\end{array}$ & $\begin{array}{l}46,1 \cdot 0 \\
47,1 \cdot 1 \\
45,0.4 \\
48,0.7 \\
47,1 \cdot 0 \\
44,1.2 \\
45,1 \cdot 1 \\
46,1.4 \\
47,0.9 \\
50,0.7 \\
49,0.9\end{array}$ & $\begin{array}{l}44,1 \cdot 1 \\
45,1 \cdot 0 \\
45,1 \cdot 3 \\
46,0 \cdot 3 \\
45,1 \cdot 3 \\
44,1 \cdot 7 \\
44,1 \cdot 7 \\
46,1 \cdot 1 \\
46,1 \cdot 1 \\
48,0.8 \\
50,1 \cdot 1\end{array}$ \\
\hline
\end{tabular}

* $<0.05$ (unpaired $t$ test)

$t \mathrm{p}<0.01$ (unpaired $t$ test)

*, tsignificant difference between the two groups

In table 6 the column headings Ipsilateral and Contralateral should be transposed.

Table 6 Analysis of regional cerebral blood flow

\begin{tabular}{|c|c|c|c|c|}
\hline \multicolumn{5}{|c|}{21 areas measured bilaterally, $N=12:$ mean values, $S E M,\left(\mathrm{ml} 100 \mathrm{~g}^{-1} \min ^{-1}\right)$} \\
\hline & \multicolumn{2}{|c|}{ Nimodipine } & \multicolumn{2}{|c|}{ Vehicle } \\
\hline & Contralateral & Ipsilateral & Contralateral & Ipsilateral \\
\hline $\begin{array}{l}\text { Frontal cortex } \\
\text { Cingulate cortex } \\
\text { Caudate nucleus }\end{array}$ & $\begin{array}{l}166,22 \cdot 8 \\
178,38 \cdot 4\end{array}$ & $\begin{array}{l}150,31 \cdot 5 \\
146,25 \cdot 3^{*}\end{array}$ & $\begin{array}{l}121,15 \cdot 3 \\
131,22 \cdot 0\end{array}$ & $\begin{array}{c}117,29 \cdot 0 \\
96,12 \cdot 0^{*}\end{array}$ \\
\hline $\begin{array}{l}\text { Anterior -High } \\
\text { Middle - - High } \\
\text { Posterior - - How } \\
\text {-Low } \\
\text { Hypothalamus } \\
\text { Sensorimotor cortex } \\
\text { Parietal cortex } \\
\text { Lateral geniculate } \\
\text { Thalamus } \\
\text { Internal capsule } \\
\text { Corpus callosum } \\
\text { Hippocampus } \\
\text { Red nucleus } \\
\text { Superior colliculus } \\
\text { Visual cortex } \\
\text { Pons } \\
\text { Cerebellum }\end{array}$ & $\begin{array}{l}148,24 \cdot 2 \\
126,15 \cdot 8 \\
141,10 \cdot 9 \\
117,12 \cdot 2 \\
135,16 \cdot 9 \\
88,10 \cdot 2 \\
114,11.9 \\
163,25 \cdot 8 \\
199,45 \cdot 0 \\
154,43 \cdot 4 \\
141,15 \cdot 7 \\
55,7 \cdot 1 \\
55,20 \cdot 5 \\
141,58 \cdot 0 \\
118,13 \cdot 0 \\
143,19.3 \\
171,18 \cdot 3 \\
98,10.9 \\
88,7 \cdot 7\end{array}$ & $\begin{array}{c}106,25 \cdot 0 \\
70,17 \cdot 6 * \\
131,29 \cdot 3 \\
47,8 \cdot 9 * \\
122,20 \cdot 3 \\
60,15 \cdot 6 \\
114,10 \cdot 3 \\
149,27 \cdot 3 \\
209,68 \cdot 5 \\
144,35 \cdot 0 \\
131,19 \cdot 6 \\
55,8 \cdot 8 \\
61,24 \cdot 4 \\
93,16 \cdot 6 \\
115,12 \cdot 7 \\
147,18 \cdot 6 \\
156,29 \cdot 9 \\
90,9 \cdot 3 \\
92,10 \cdot 1\end{array}$ & $\begin{array}{l}135,17 \cdot 4 \\
114,13 \cdot 7 \\
137,14 \cdot 4 \\
111,17 \cdot 0 \\
135,15 \cdot 5 \\
93,15 \cdot 4 \\
107,17 \cdot 3 \\
139,16 \cdot 8 \\
127,20 \cdot 8 \\
124,26 \cdot 6 \\
128,18 \cdot 5 \\
56,8 \cdot 3 \\
58,7 \cdot 6 \\
106,15 \cdot 0 \\
121,22 \cdot 5 \\
147,14 \cdot 6 \\
157,30 \cdot 0 \\
85,9 \cdot 0 \\
91,7 \cdot 2\end{array}$ & $\begin{array}{c}97,16 \cdot 0 \\
41,11 \cdot 2 * \\
87,20 \cdot 1 \\
32,5 \cdot 1 * \\
88,21 \cdot 3 \\
42,12 \cdot 8^{*} \\
93,16 \cdot 7 \\
122,22 \cdot 1 \\
127,25 \cdot 1 \\
114,24 \cdot 3 \\
123,19 \cdot 9 \\
51,5 \cdot 6 \\
51,5 \cdot 6 \\
114,20 \cdot 1 \\
118,19 \cdot 3 \\
132,20 \cdot 5 \\
174,44 \cdot 7 \\
98,12 \cdot 8 \\
86,10 \cdot 0\end{array}$ \\
\hline
\end{tabular}

*significant side-to side difference between structures in the same group $\mathrm{p}<0.05$ Unpaired $t$ test 